\title{
Humanin Attenuates NMDA-Induced Excitotoxicity by Inhibiting ROS-dependent JNK/p38 MAPK Pathway
}

\author{
Xiaorong Yang ${ }^{1, *,+} \oplus$, Hongmei Zhang ${ }^{2,+}{ }^{+}$Jinzi $\mathrm{Wu}^{3}$, Litian Yin ${ }^{1}$, Liang-Jun Yan $^{3}{ }^{\circledR}$ and \\ Ce Zhang ${ }^{1, *}$ \\ 1 National Key Disciplines, Key Laboratory for Cellular Physiology of Ministry of Education, Department of \\ Neurobiology, Shanxi Medical University, Taiyuan 030001, China; yinlitian@126.com \\ 2 Department of Environmental Health, Shanxi Medical University, Taiyuan 030001, China; \\ zhhm_108@163.com \\ 3 Department of Pharmaceutical Sciences, UNT System College of Pharmacy, University of North Texas Health \\ Science Center, Fort Worth, TX 76107, USA; Jinzi.Wu@unthsc.edu (J.W.); Liang-jun.yan@unthsc.edu (L.-J.Y.) \\ * Correspondence: rong_522522@163.com (X.Y.); cezh2002@yahoo.com (C.Z.); Tel.: +86-13503517453 (X.Y.); \\ +86-13753184051 (C.Z.) \\ + These authors contributed equally to this work.
}

Received: 16 August 2018; Accepted: 26 September 2018; Published: 29 September 2018

\begin{abstract}
Humanin (HN) is a novel 24-amino acid peptide that protects neurons against $\mathrm{N}$-methyl-D-aspartate (NMDA)-induced toxicity. However, the contribution of the different mitogen-activated protein kinases (MAPKs) signals to HN neuroprotection against NMDA neurotoxicity remains unclear. The present study was therefore aimed to investigate neuroprotective mechanisms of $\mathrm{HN}$. We analyzed intracellular $\mathrm{Ca}^{2+}$ levels, reactive oxygen species (ROS) production, and the MAPKs signal transduction cascade using an in vitro NMDA-mediated excitotoxicity of cortical neurons model. Results showed that: (1) HN attenuated NMDA-induced neuronal insults by increasing cell viability, decreasing lactate dehydrogenase (LDH) release, and increasing cell survival; (2) HN reversed NMDA-induced increase in intracellular calcium; (3) pretreatment by $\mathrm{HN}$ or 1,2-bis(2-aminophenoxy)ethane- $N, N, N^{\prime}, N^{\prime}$-tetraacetic acid (BAPTA-AM), an intracellular calcium chelator, decreased ROS generation after NMDA exposure; (4) administration of HN or N-Acetyl-L-cysteine (NAC), a ROS scavenger, inhibited NMDA-induced JNK and p38 MAPK activation. These results indicated that $\mathrm{HN}$ reduced intracellular elevation of $\mathrm{Ca}^{2+}$ levels, which, in turn, inhibited ROS generation and subsequent JNK and p38 MAPK activation that are involved in promoting cell survival in NMDA-induced excitotoxicity. Therefore, the present study suggests that inhibition of ROS-dependent JNK/p38 MAPK signaling pathway serves an effective strategy for HN neuroprotection against certain neurological diseases.
\end{abstract}

Keywords: HN; neuroprotection; NMDA; excitotoxicity; MAPKs; ROS

\section{Introduction}

Glutamate is a primary excitatory amino acid neurotransmitter in mammalian central nervous system (CNS) and activation of glutamate receptors including N-methyl-D-aspartate (NMDA) receptor plays crucial roles in neural development, synaptic plasticity, transmission, learning and memory $[1,2]$. Under pathological conditions, the excessive release and accumulation of glutamate over-activates NMDA receptor which cause intracellular $\mathrm{Ca}^{2+}$ overload and an enzymatic cascade of events resulting ultimately in cell death through collapse of the mitochondrial membrane, ER stress, increased formation of reactive oxygen species (ROS), and reactive nitrogen species, nitric oxide, lipid peroxidation, 
and DNA damage [3,4]. This process is commonly known as excitotoxicity $[2,5,6]$. A wide range of acute and chronic brain injury diseases, such as stroke/ischemia, epilepsy, and certain neurodegenerative disorders have been linked to NMDA receptor-mediated excitotoxicity [7]. Therefore, NMDA-induced excitotoxicity is a useful tool to evaluate neurotoxicity in isolated cells and is a good model of nerve injury that mimics closely the situation in vivo [8].

Mitogen-activated protein kinases (MAPKs), which include extracellular signal-regulated kinase (ERK1/2), c-Jun N-terminal kinase (JNK), and p38 MAPK are evolutionarily conserved enzymes that link cell-surface receptors to intracellular regulatory targets, and have been shown to be involved in the glutamate/NMDA-induced excitotoxicity [9-13]. While the exact mechanism of excitotoxicity is not clear yet, it may however be mediated through activation of ERK1/2, JNK, and p38 MAPK [14-16]. Consistent with these findings, we also found the involvement of JNK and p38 MAPK pathways in NMDA-induced cell death of rat cortical neurons [17].

Humanin (HN) is a polypeptide of 24 amino acids that was first isolated from brains of patients with Alzheimer's disease (AD) $[18,19]$. HN is best known for its ability to suppress neuronal cell death induced by AD-related insults such as familial AD proteins and neurotoxic A $\beta$ peptides [20]. Recently, evidence has revealed that $\mathrm{HN}$ has a broader spectrum of neuroprotective activity [21,22]. For example, $\mathrm{HN}$ has been shown to rescue neurons from NMDA-induced toxicity [23,24]. However, it remains sketchy that the neuroprotection of $\mathrm{HN}$ is mediated by the MAPK signals. The present study was carried out to investigate the molecular mechanisms underlying the neuroprotection of $\mathrm{HN}$ against NMDA neurotoxicity.

\section{Results}

\subsection{Humanin (HN) Prevents from NMDA-Induced Neuronal Insults}

We found that the optimal excitotoxicity was induced at $24 \mathrm{~h}$ after NMDA $(100 \mu \mathrm{M})$ exposure for two $h$ in primary cortical neurons. As shown in Figure 1, pretreatment with different concentrations $(10,20$ and $40 \mu \mathrm{M})$ of $\mathrm{HN}$ reversed NMDA-induced excitotoxicity including a decrease in cell viability $(p<0.05)$ (Figure 1a), an increase in LDH release $(p<0.05)$ (Figure 1b) and a decrease in cell survival rate $(p<0.05)$ (Figure $1 \mathrm{c})$, as measured by WST-8 assay, LDH assay, and Calcein-AM assay. However, five $\mu \mathrm{M} H \mathrm{H}$ had no neuroprotective effects against NMDA-induced neuronal insults $(p>0.05)$. Additionally, pretreatment of $20 \mu \mathrm{M}$ unrelated peptide (UP), as a control for $\mathrm{HN}$, did not affect the excitotoxic effects $(p>0.05)$. MK-801 $(10 \mu \mathrm{M})$, a noncompetitive NMDA receptor antagonist, fully abolished the insults trigged by NMDA $(p<0.05)$, supporting that the toxic effects were induced by NMDA. These results suggest that HN counteracts NMDA-induced neuronal insults. In the following experiments, $\mathrm{HN}$ was administered at the concentration of $20 \mu \mathrm{M}$ based on the significant protective effects observed in the $20 \mu \mathrm{M}$ HN group.

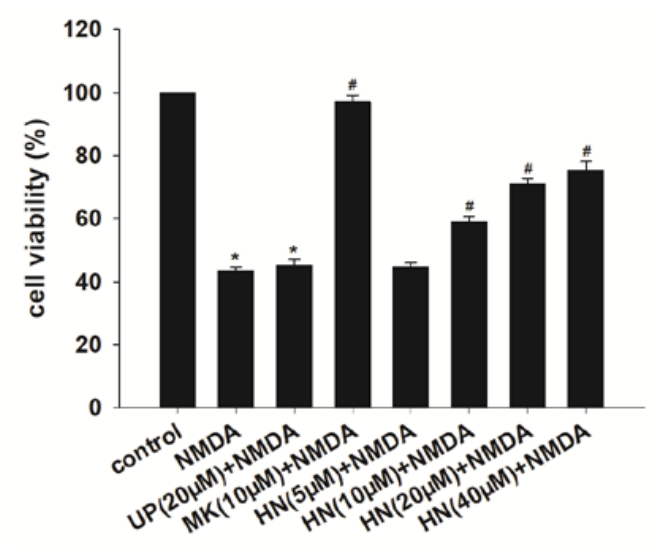

(a)

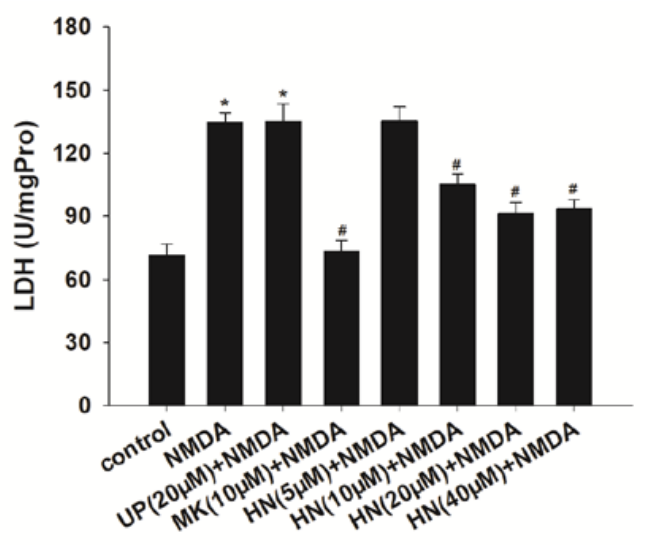

(b)

Figure 1. Cont. 

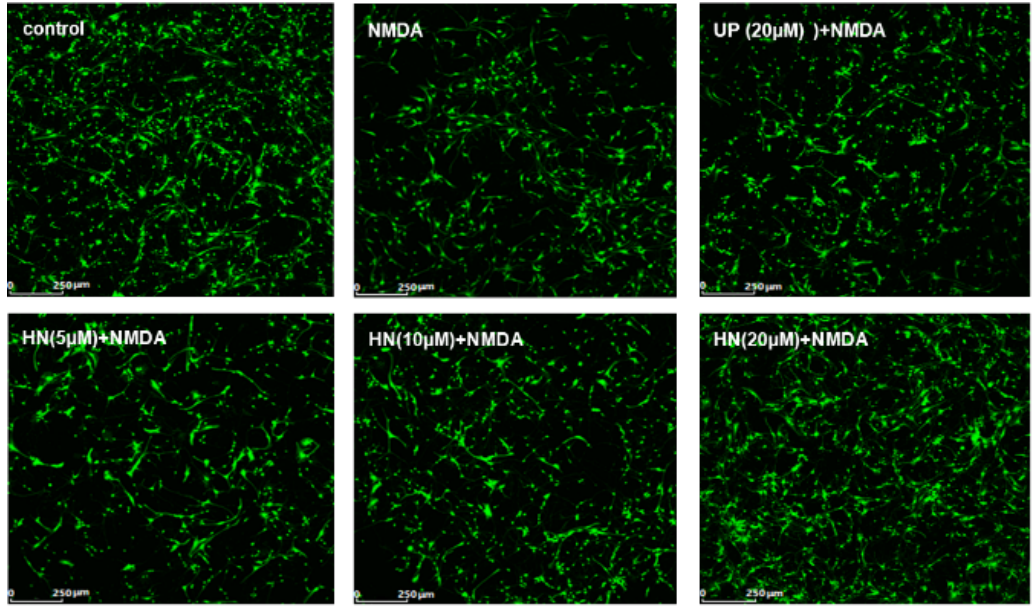

(c)
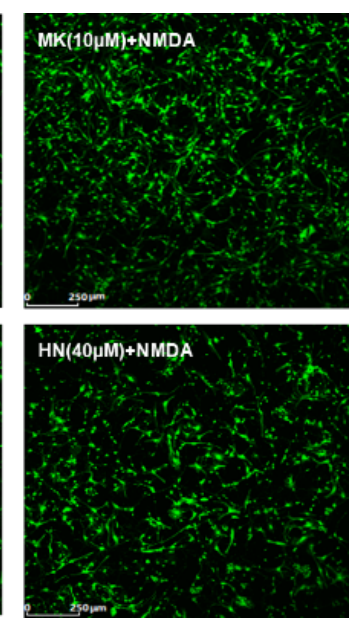

Figure 1. Effects of HN on NMDA-induced neuronal insults. (a) Pretreatment of HN $(10 \mu \mathrm{M}, 20 \mu \mathrm{M}$ $40 \mu \mathrm{M})$ improved cell viability compared with NMDA treatment group $(p<0.05)$; (b)Pretreatment of $\mathrm{HN}(10,20,40 \mu \mathrm{M})$ reduced LDH activity (U/mgPro) in cell supernatant induced by NMDA $(p<0.05)$; (c) Pretreatment of $\mathrm{HN}(10,20,40 \mu \mathrm{M})$ reversed NMDA-mediated the decrease in cell survival rate $(p<0.05)$. UP: unrelated peptide; MK: MK-801. Each value represents the mean \pm S.E.M. of six independent experiments. ${ }^{*} p<0.05$ vs. control group, $\# p<0.05$ vs. NMDA group.

\subsection{Humanin (HN) Attenuated NMDA-Induced Elevation of Intracellular Calcium}

As shown in Figure 2, intracellular $\mathrm{Ca}^{2+}$ concentration $\left(\left[\mathrm{Ca}^{2+}\right]_{\mathrm{i}}\right)$ after NMDA exposure of cortical neurons is 2.5 fold higher, when compared to the control $(p<0.05)$. MK-801 $(10 \mu \mathrm{M})$ completely inhibited the increase, suggesting that the elevation of $\left[\mathrm{Ca}^{2+}\right]_{i}$ was caused by NMDA. Pretreatment with $\mathrm{HN}(20 \mu \mathrm{M})$ significantly extenuated intracellular calcium overload triggered by NMDA $(p<0.05)$. We also found that administration of UP $(20 \mu \mathrm{M})$ did not inhibit NMDA-induced elevation of intracellular calcium $(p>0.05)$.

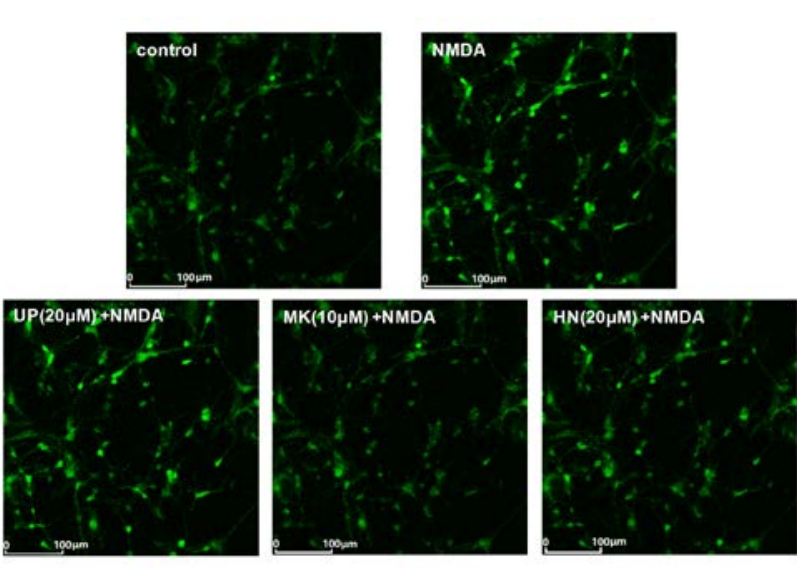

(a)

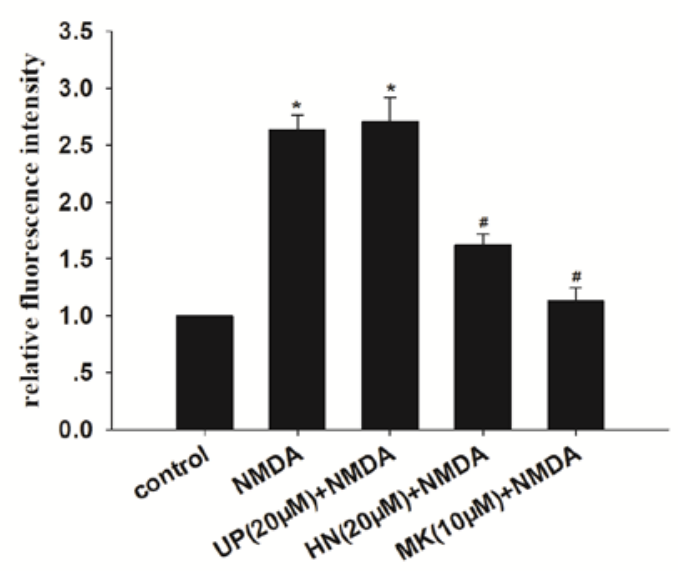

(b)

Figure 2. HN suppressed intracellular calcium overload in NMDA-induced excitotoxicity. (a) Intracellular $\mathrm{Ca}^{2+}$ was measured via live cell imaging; (b) Represents bar diagram of relative fluorescence intensity. UP: unrelated peptide; MK: MK-801. Each value represents the mean \pm S.E.M. of three independent experiments. ${ }^{*} p<0.05$ vs. control group, $\# p<0.05$ vs. NMDA group.

\subsection{Decrease in Reactive Oxygen Species Levels by HN, BAPTA-AM or NAC after NMDA Exposure}

To clarify the time course of ROS generation during excitotoxicity, we measured the production of ROS and found that NMDA induced an increase of ROS with a peak response at six $\mathrm{h}$ (data not shown). 
NAC ( $N$-acetyl-L-cysteine) is commonly used to identify and test ROS (reactive oxygen species) inducers, and to inhibit ROS generation. We respectively examined the effects of ROS scavenger NAC, neuroprotective peptide $\mathrm{HN}$, and intracellular calcium chelator 1,2-bis(2-aminophenoxy) ethane- $N, N, N^{\prime}, N^{\prime}$-tetraacetic acid (BAPTA-AM) on ROS generation after NMDA treatment. As shown in Figure 3, administration of HN $(20 \mu \mathrm{M})$ reduced NMDA-induced production of ROS by $45.71 \%$ $(p<0.05)$. MK-801 $(10 \mu \mathrm{M})$, BAPTA-AM $(10 \mu \mathrm{M})$ or NAC $(100 \mu \mathrm{M})$ fully blocked NMDA-induced ROS generation $(p<0.05)$. Pretreatment of UP $(20 \mu \mathrm{M})$ had no effects on NMDA-induced ROS generation $(p>0.05)$.

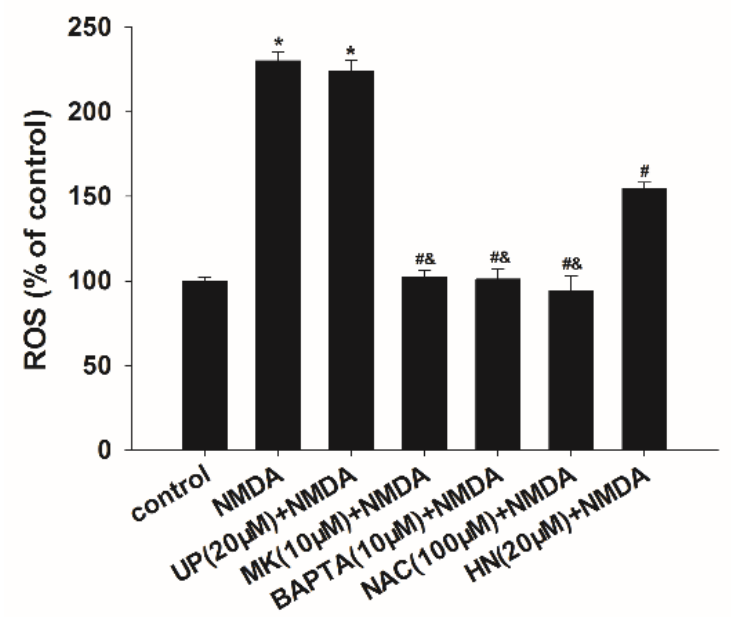

Figure 3. Inhibition of NMDA-induced ROS generation by HN, BAPTA-AM or NAC. UP: unrelated peptide; MK: MK-801; BAPTA: BAPTA-AM; NAC: N-Acetyl-L-cysteine. Each value represents the mean \pm S.E.M. of three independent experiments. ${ }^{*} p<0.05$ vs. control group, $\# p<0.05$ vs. NMDA group, \& $p<0.05$ vs. HN + NMDA group.

\subsection{NMDA-Induced MAPKs Activation were Attenuated by HN or NAC}

To further evaluate the involvement of MAPKs in the excitotoxicity, the phosphorylation of MAPKs was examined at various periods of time after NMDA administration (zero $\mathrm{h}$ to $24 \mathrm{~h}$ ). As shown in Figure 4, phosphorylation levels of JNK and p38 MAPK followed by NMDA were significantly higher at $3,6,12 \mathrm{~h}$, and $24 \mathrm{~h}$ than that in the untreated control group (zero $\mathrm{h}$ ), with a maximal activation at $12 \mathrm{~h}$ after NMDA treatment $(p<0.05)$. Total levels of JNK, p38 MAPK and $\beta$-actin were virtually unchanged under all of these experimental conditions. The results indicated that NMDA induced the activation of JNK and p38 MAPK in a time-dependent manner. While NMDA did not affect the phosphorylation of ERK1/2 $(p>0.05)$, indicating that ERK1/2 was not involved in the neurotoxicity.

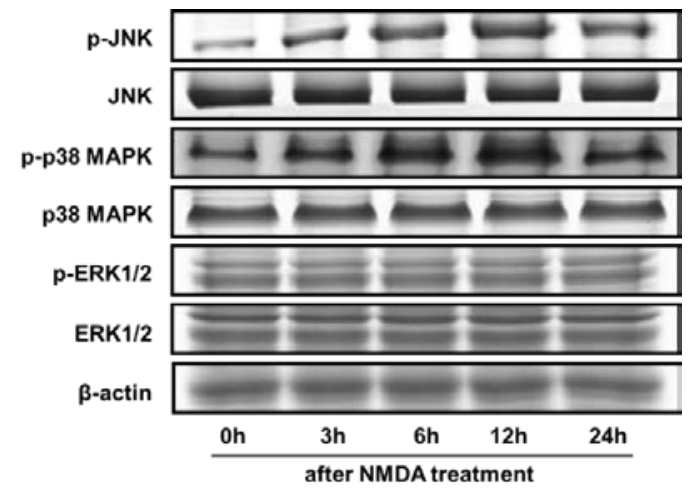

Figure 4. The time course of MAPKs activation in response to NMDA. Representative immunoblots depicting the phosphorylation of JNK, p38 MAPK, and ERK1/2 at 0-24 h after NMDA treatment. However, no significant changes were found in total forms. $\beta$-actin was used as a loading control. 
As shown in Figure 5, pretreatment of NAC $(100 \mu \mathrm{M})$ significantly reduced NMDA-induced JNK and p38 MAPK phosphorylation $(p<0.05)$, which indicated the involvement of ROS in MAPKs signaling pathways. Similarly, HN $(20 \mu \mathrm{M})$ also suppressed JNK and p38 MAPK phosphorylation $(p<0.05)$. In addition, there was a difference between the NAC + NMDA and HN group $(p<0.05)$. MK-801 $(10 \mu \mathrm{M})$ completely blocked the effects caused by NMDA $(p<0.05)$. UP $(20 \mu \mathrm{M})$ did not affect the expression of these proteins when compared with NMDA group $(p>0.05)$.

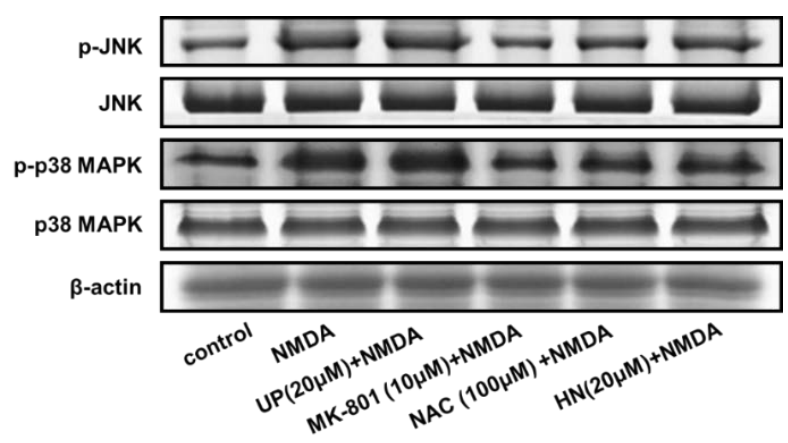

(a)

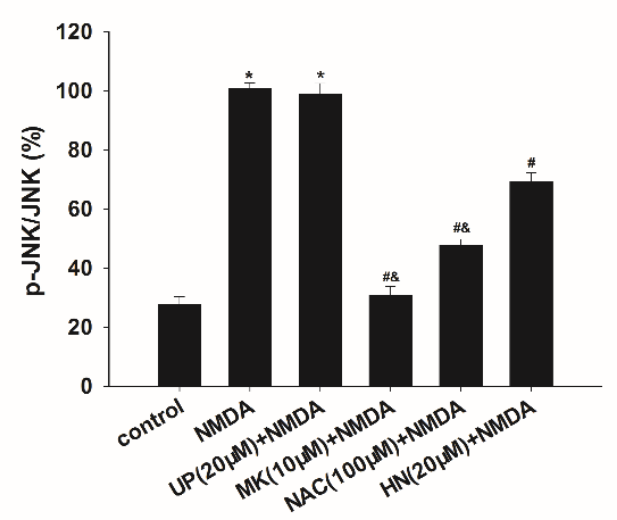

(b)

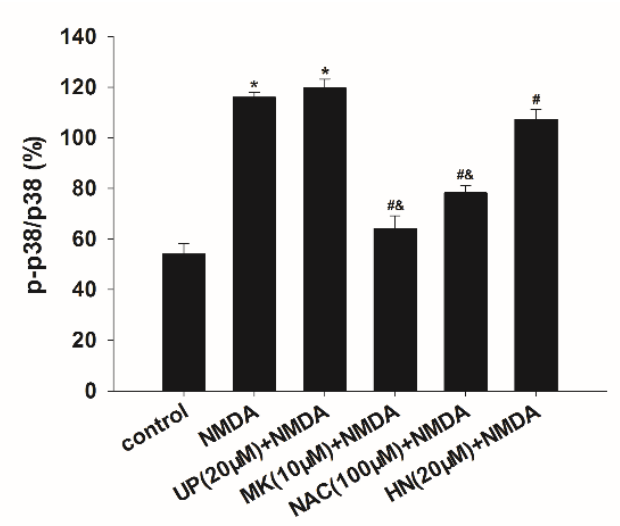

(c)

Figure 5. Effects of HN or NAC on the expression levels of phosphorylated JNK and p38 MAPK family proteins in NMDA-induced toxicity. (a) Representative Immunoblots and (b) densitometry histograms depicting NMDA induced upregulation of p-JNK, and (c) p-p38 MAPK proteins and their attenuation by $\mathrm{HN}$ or NAC. However, no significant changes were found in total forms. $\beta$-actin was used as a loading control. UP: unrelated peptide; MK: MK-801; NAC: N-Acetyl-L-cysteine. Each value represents the mean \pm S.E.M. of three independent experiments. ${ }^{*} p<0.05$ vs. control group, $\# p<0.05$ vs. NMDA group, and \& $p<0.05$ vs. HN + NMDA group.

\section{Discussion}

Results of the present study revealed that HN ameliorated the NMDA-induced death of primary cortical neuron. HN rescued cells from NMDA-induced excitotoxicity by abating intracellular calcium levels, attenuating excessive generation of ROS, and invoking inhibition of MAPK family proteins.

As a well-known neuroprotective factor, $\mathrm{HN}$ was first found in certain regions of human $\mathrm{AD}$ brain. As has been reported, $\mathrm{HN}$ protected neurons against $\mathrm{A} \beta$, okadaic acid-induced neurotoxicity, as well as mutational APP, PS1, and PS2-induced neuronal death $[18,25,26]$ in vitro, and also exerts neuroprotection in the model of $\mathrm{AD}$ and myocardial ischemia-reperfusion (I/R) injury in vivo $[27,28]$. In the present study, we found that preincubation of cortical neurons with HN prevented NMDA-induced excitotoxicity including the decrease in cell viability, the increase in LDH release and cell death triggered by NMDA. These results further confirmed that HN has 
neuroprotection in NMDA-induced excitotoxicity. Thus, a growing body of evidence has indicated the neuroprotective effects of $\mathrm{HN}$.

We found pretreatment with $\mathrm{HN}$ attenuated $\mathrm{Ca}^{2+}$ increase trigged by NMDA. It is well known that NMDA contributes to significant increase in intracellular $\mathrm{Ca}^{2+}$ concentrations, which induce various pathologic processes such as oxidant stress, ATP depletion, loss of mitochondrial membrane potential that ultimately leads to cell death $[3,4]$. The $\mathrm{Ca}^{2+}$ influx through voltage-gated $\mathrm{Ca}^{2+}$ channel does not invoke cell death whereas $\mathrm{Ca}^{2+}$ entry via NMDA receptor is linked with $\mathrm{Ca}^{2+}$-dependent excitotoxicity [29]. These suggest that the mechanism of $\mathrm{HN}$ neuroprotection in rat cortical neuron maybe through antagonism of the NMDA receptor. Nonetheless, there is also a conflicting report showing that $\mathrm{HN}$ failed to inhibit intracellular $\mathrm{Ca}^{2+}$ overload triggered by NMDA [23,30]. The reason for the discrepancy is unclear, but one possibility could be due to different concentrations of HN used between these two studies. It has been reported that $\mathrm{HN}$ exerts protective effects via its putative receptor on the cell membrane, including $G$ protein-coupled receptors, formyl peptide-receptor-like (FPRL)-1 and 2 [31,32]; and a trimeric receptor complex composed of ciliary neurotrophic factor receptor $\alpha$ (CNTFR), gp130, and the IL-27 receptor subunit, WSX-1.7 [33]; and the gp130 receptor [24]. These findings suggest that different mechanisms underlie the $\mathrm{HN}$ neuroprotection in different cells in vitro.

In the present study, pretreatment with HN significantly attenuated ROS production in the excitotoxicity. The result agrees with a recent report of an appreciable ability of $\mathrm{HN}$ to decrease the ROS levels in NMDA-induced excitotoxicity [23]. Additionally, we also found that administration of BAPTA-AM fully abolished NMDA-induced ROS generation, suggesting that ROS generation triggered by NMDA is $\mathrm{Ca}^{2+}$-dependent. It has been shown that overload of intracellular calcium levels induced by excitotoxicity leads to ROS generation, oxidative stress, and ultimately cell death [34]. The present results indicated that $\mathrm{HN}$ attenuated intracellular $\mathrm{Ca}^{2+}$ influx that in turn decreased ROS levels and then promote cell survival.

We then observed that the phosphorylation levels of JNK and p38 MAPK were significantly up-regulated in a time-dependent manner and reached a maximal response $12 \mathrm{~h}$ after NMDA treatment. Furthermore, pretreatment with HN resulted in attenuation of these increased MAPKs levels. The result suggests that HN reverses NMDA-induced neuronal insults through inhibition of JNK and p38 MAPK signaling pathway. Similarly, it has been reported that JNK1 inhibition protected cortical neurons against toxicity and reduced ischemic neuronal insults in rats [35-37]. Pharmacological blockade of p38 MAPK attenuated neuronal damage due to cerebral ischemia [38]. Recently, Dar et al. reported that glutamate exposure caused a significant increase in phosphorylation levels of JNK and p38 MAPK in Neuro2a cells and inhibition of these MAPKs proteins had protective effects [16]. Therefore, inhibition of the JNK and p38 MAPK pathways protect against excitotoxic neuronal death in vitro and stimulating the JNK and p38 MAPK pathways aggravate neuronal death. Nonetheless, we observed that NMDA did not affect ERK1/2 phosphorylation. The contribution of ERK1/2 pathway to neuronal insults in vivo and in vitro models are still so controversial. For example, ERK1/2 activation participated in neuronal insults and inhibition of ERK afforded neuroprotection against excitotoxicity and cerebral ischemia $[39,40]$, while it is also reported that facilitation of ERK activation prevents glutamate-induced apoptosis in SCN2.2 cells [41]. The role of ERK on cell survival/death seems to be associated with the model system and injury paradigm [42].

Further observation showed that pretreatment of NAC fully prevented ROS production and markedly ameliorated NMDA-induced JNK and p38 MAPK activation. Therefore, it suggests that ROS generation is required for MAPKs activities in the excitotoxicity model. ROS has been implicated in the promotion of cell death through JNK signaling pathway due to various oxidative stress exposure and effects of JNK and p38 MAPK depend on elevated ROS production [43-45]. Likewise, studies have shown that ROS production induced by Palmitate (PA) contributed to the activation of JNK and p38 MAPK, which results in autophagy and apoptosis of H9c2 cells [46]. Based on the above observation that $\mathrm{HN}$ decreased ROS levels after NMDA exposure, it is supposed that HN's 
neuroprotective strategies against NMDA-induced excitotoxicity in cortical neuron are capable of inhibiting ROS-dependent JNK and p38 MAPK activation.

Taken together, our study indicates that over-activation of NMDA receptor may trigger high $\mathrm{Ca}^{2+}$ influx and subsequent ROS generation, leading to JNK and p38 MAPK activation, resulting, ultimately, in an enzymatic cascade of events and cell death, and pretreatment of $\mathrm{HN}$ attenuates NMDA-induced excitotoxicity by inhibiting $\mathrm{Ca}^{2+}$-ROS-JNK/p38 MAPK signaling pathway. We cannot, however, rule out the possibility that other pathways are also involved in NMDA toxicity and $\mathrm{HN}$-mediated neuroprotection. Nonetheless, this study further elucidates the mechanism underlying the HN-mediated neuroprotective signal. Understanding the mechanism for the rescue function of $\mathrm{HN}$ would provide an insight into the novel avenue toward the development of neurodegenerative disease therapies.

\section{Materials and Methods}

\subsection{Reagents}

Synthetic Humanin (HN) and unrelated peptide (UP) were purchased from Sangon biotech (Shanghai China). The sequences of HN and UP are MAPRGFSCLLLLTSEIDLPVKRRA and IYMCILTVYPAEAISQWGRDLAVD, respectively. The Neurobasal/B27 and DMEM/F-12 were purchased from Gibco-BRL (Grand Island, NY, USA). Poly-D-lysine (MW 150,000-300,000), trypsin, arabinoside cytosine, Calcein-AM, N-Acetyl-L-cysteine (NAC), NMDA, and MK-801 were all purchased from Sigma-Aldrich (St. Louis, MO, USA). Cell Counting Kit-8 (CCK-8) was from Dojindo (Kumamoto, Japan), and Kit of LDH was from Njjcbio (Nanjing, China). Fluo-3AM and 2',7'-dichlorodihydrofluorescein diacetate (H2DCFDA) were from Invitrogen (Carlsbad, California, USA). MAPK and Phospho-MAPK Family Antibody Sampler Kits were obtained from Cell Signaling Technology (Beverly, MA, USA). $\beta$-actin was from Santa Cruz Biotechnology (Santa Cruz, CA, USA). New born Wistar rats were from the Experimental Animal Center of Shanxi Medical University.

\subsection{Animal and Cell Culture}

1-3-day-old Wistar rats were supplied by the Research Animal Center of Shanxi Medical University, with approval of the Shanxi Committee on Ethics of Animal Research (approval No. SYXK[JIN]2015-0001, approved on 4 March 2015). Primary cortical cells were isolated from Wistar rats and were cultured as previously described [47]. In brief, cortical neurons from rats anesthetized with ketamine (intraperitoneal injection, $100 \mathrm{mg} / \mathrm{kg}, 3 \mathrm{~min}$ ) were dissected and digested in $0.025 \%$ trypsin, followed by centrifugation at $800 \times g$ for $5 \mathrm{~min}$. Cells were re-suspended in Neurobasal/B27 medium, and cultured at $37{ }^{\circ} \mathrm{C}$ in $5 \% \mathrm{CO}_{2}$. Arabinoside cytosin $(10 \mu \mathrm{M})$ was added after $24 \mathrm{~h}$ to inhibit non-neuronal cell growth. Only mature neuronal cells (10-12 days) in vitro were used for the experiments.

\subsection{Treatments}

After overnight incubation allowing the cells to reach $80 \%$ confluency, cultured cortical neurons were treated with $100 \mu \mathrm{M}$ NMDA for $2 \mathrm{~h}$. HN $(20 \mu \mathrm{M})$ or NAC (N-Acetyl-L-cysteine) $(100 \mu \mathrm{M})$ was added to cultures $16 \mathrm{~h}$ prior to NMDA induction. BAPTA-AM $(10 \mu \mathrm{M})$ was respectively added $1 \mathrm{~h}$ before NMDA treatment. MK-801 $(10 \mu \mathrm{M})$ and NMDA were simultaneously added to $\mathrm{Mg}^{2+}$-free Locke's buffer in the NMDA + MK-801 group. Control cells were incubated with drug-free $\mathrm{Mg}^{2+}$-free Locke's buffer and grown at $37^{\circ} \mathrm{C}$ in an atmosphere containing $5 \% \mathrm{CO}_{2}$.

\subsection{Cell Viability Assay}

Cells were seeded in 96-well plates, and cell viability was assayed $24 \mathrm{~h}$ after NMDA exposure. Ten microliters of cck-8 solution was administrated into each well, following incubation for $2 \mathrm{~h}$ at 
$37^{\circ} \mathrm{C}$. Absorbance at $490 \mathrm{~nm}$ was measured using a microplate reader (Packard Instrument Company, Meriden, CT, USA).

\subsection{Lactate Dehydrogenase (LDH) Assay}

Cell injury induced by NMDA was quantitatively assessed by the measurement of LDH released from damaged cells. In this study, we used serum-free medium when detected LDH [48,49]. The formula was Neurobasal $96.75 \mathrm{~mL}, \mathrm{~B} 272 \mathrm{~mL}$, L-glutamine $0.25 \mathrm{~mL}$, and mycillin $1 \mathrm{~mL}$ to configure $100 \mathrm{~mL}$ serum-free medium. This combination had been shown to reduce glia to less than $0.5 \%$. The cells were plated in 24-well plates. At $24 \mathrm{~h}$ after NMDA exposure, $500 \mu \mathrm{L}$ of supernatant was collected from each well and mixed with $1.3 \mathrm{~mL}$ of NADH $(0.217 \mathrm{mmoL} / \mathrm{L})$ and $1.3 \mathrm{~mL}$ of sodium pyruvate $(1.77 \mathrm{mmoL} / \mathrm{L})$ in the modiWed Krebs-Henseleit buffer for $30 \mathrm{~s}$ at $37^{\circ} \mathrm{C}$. The absorbance was measured at $450 \mathrm{~nm}$ using a microplate reader and the $\mathrm{LDH}$ activity was expressed as $\mathrm{U} / \mathrm{mgPro}$.

\subsection{Calcein-AM Assay}

Calcein-AM solution $(20 \mu \mathrm{M})$ was added to coverslips, the cells were incubated at $37^{\circ} \mathrm{C}$ for $30 \mathrm{~min}$ and were washed twice with PBS. Then, the cells were examined under fluorescence microscopy (IX51, Olympus, Tokyo, Japan).

\subsection{Confocal Calcium Imaging/Measurement}

Intracellular free $\mathrm{Ca}^{2+}$ was measured with fluorescent dye Fluo-3/AM utilizing confocal laser scanning microscopy (TCS SP5, Leica, Mannheim, Germany). Briefly, cells were incubated with $3 \mu \mathrm{M}$ Fluo-3/AM for $30 \mathrm{~min}$ at $37^{\circ} \mathrm{C}$ in the dark. The cells were washed with PBS to remove any unbound dye. Live video images of selected neurons under microscopic field (approximately 10-30 neurons per field) were recorded with a confocal laser-scanning microscope. Excitation wavelength of $490 \mathrm{~nm}$ and emission wavelength of $528 \mathrm{~nm}$ were selected for the fluo-3 fluorescence. Quantitative analysis of the images was performed by Leica image analysis software by calculating the florescence intensity of the region of interest (ROI).

\subsection{Measurement of Reactive Oxygen Species (ROS)}

Intracellular ROS level was measured using the fluorescent probe H2DCFDA. Briefly, the cells $\left(1 \times 10^{5}\right)$ in 6-well plates were incubated with $10 \mu \mathrm{M} \mathrm{H} 2 \mathrm{DCFDA}$ for $30 \mathrm{~min}$ at $37^{\circ} \mathrm{C}$ in the dark. After incubation, the cells were washed with $1 \times$ PBS, and resuspended in PBS, and analyzed by flow cytometry. The fluorescence emitted at $488 \mathrm{~nm}$ was measured with a FACS Calibur flow cytometer (BD FACSAriaT) and analyzed using the CELL Quest software. Ten thousand cells were examined for each sample. The values were expressed as percentage of fluorescence in the control. ROS levels were expressed as a percentage of control.

\subsection{Western Blot Analysis}

Cells were lysed in a lysis buffer [10 mM Tris-HCl (pH 7.4), $1 \mathrm{mM}$ EDTA, and 1\% Triton $\mathrm{X}-100]$. Cleared cell lysates were obtained after centrifugation at $10,000 \times \mathrm{g}$ for $30 \mathrm{~min}$ at $4{ }^{\circ} \mathrm{C}$. After measurement of protein concentration using a BCA Protein Assay kit, cell lysates (30-50 $\mu \mathrm{g} /$ lane) were subjected to SDS-PAGE, and separated proteins were electrotransferred to nitrocellulose membranes. The membranes were washed in Tris-buffered saline (TBS) containing $0.1 \%$ Tween 20 and $3 \%$ bovine serum albumin (BSA). The membranes were incubated overnight at $4{ }^{\circ} \mathrm{C}$ in TBS containing $3 \%$ BSA and one of the following primary antibodies: p-ERK1/2, ERK1/2, p-JNK, JNK, p-p38 MAPK, p38 MAPK, and $\beta$-actin. Subsequently, the labeled proteins were incubated with an HRP-conjugated goat anti-rabbit IgG for $2 \mathrm{~h}$. Blots were developed with the ECL chemiluminescence system and were captured on autoradiographic films (Kodak Image Station 440, Kodak GmbH, Stuttgart, Germany). 
Films were scanned and densitometric analysis of the bands was performed with AlphaEase Image Analysis Software (Version 5.0.1, Alpha Innotech, San Leandro, CA, USA).

\subsection{Statistical Analysis}

Statistical analyses were performed using SPSS 21.0 (SPSS Inc., Chicago, IL, USA). The data were expressed as means \pm S.E.M. of at least three independent experiments. One-way analysis of variance (ANOVA) with bonferroni post-hoc test was used for statistical comparisons. $p<0.05$ was considered to be significant.

Author Contributions: Conceptualization, X.Y. and C.Z.; Methodology, H.Z.; Validation, J.W.; Formal Analysis, L.Y.; Investigation, X.Y. and H.Z.; Resources, X.Y. and C.Z.; Data Curation, L.Y.; Writing-Original Draft Preparation, X.Y.; Writing—Review \& Editing, L-J.Y.; Visualization, X.Y.; Project Administration, X.Y.; Funding Acquisition, X.Y. and C.Z.

Funding: This research was funded by the National Natural Science Foundation of China [no. 31000481, and no. 81601167], the Natural Science Foundation of Shanxi Province, China [no. 2011011040-2], the Fund for Shanxi Key Subjects Construction [FSKSC], Shanxi "1331 Project" Key Subjects Construction [1331KSC], Key Laboratory of Cellular Physiology (Shanxi Medical University)in Shanxi Province, Science and Technology Innovation Project of Shanxi Province [201802061], and Research Project Supported by Shanxi Scholarship Council of China [2017-059].

Acknowledgments: We thank the other academic staff members in Ce Zhang's group at Shanxi Medical University.

Conflicts of Interest: The authors declare no conflict of interest.

\section{Abbreviations}

$\begin{array}{ll}\text { CNS } & \text { central nervous system } \\ \text { HN } & \text { Humanin } \\ \text { UP } & \text { unrelated peptide } \\ \text { NMDA } & \text { N-methyl-D-aspartate } \\ \text { MK-801 } & 5 \text { S,10R)-(+)-5-Methyl-10,11-dihydro-5H-dibenzo[a,d]cyclohepten-5,10-imine maleate } \\ \text { MAPKs } & \text { Mitogen- activated protein kinases } \\ \text { ERK1/2 } & \text { extracellar signal-regulated protein kinase } \\ \text { JNK } & \text { c-Jun N-terminal kinase } \\ \text { BAPTA-AM } & 1,2 \text {-bis(2-aminophenoxy)ethane- } N, N, N^{\prime}, N^{\prime} \text {-tetraacetic acid } \\ \text { LDH } & \text { lactate dehydrogenase } \\ \text { AD } & \text { Alzheimer's disease } \\ \text { ROS } & \text { reactive oxygen species } \\ \text { NAC } & N \text {-Acetyl-L-cysteine } \\ \text { H2DCFDA } & 2 \text { ', } 7^{\prime} \text {-dichlorodihydrofluorescein diacetate } \\ \text { FPRL } & \text { formyl peptide-receptor-like } \\ \text { CNTFR } & \text { ciliary neurotrophic factor receptor } \alpha\end{array}$

\section{References}

1. Greengard, P. The neurobiology of slow synaptic transmission. Science 2001, 294, 1024-1030. [CrossRef] [PubMed]

2. Gonda, X. Basic pharmacology of NMDA receptors. Curr. Pharm. Des. 2012, 18, 1558-1567. [CrossRef] [PubMed]

3. Dar, N.J.; Bhat, J.A.; Satti, N.K.; Sharma, P.R.; Hamid, A.; Ahmad, M. Withanone, an Active Constituent from Withania somnifera, Affords Protection Against NMDA-Induced Excitotoxicity in Neuron-Like Cells. Mol. Neurobiol. 2017, 54, 5061-5073. [CrossRef] [PubMed]

4. Kritis, A.A.; Stamoula, E.G.; Paniskaki, K.A.; Vavilis, T.D. Researching glutamate-Induced cytotoxicity in different cell lines: A comparative/collective analysis/study. Front. Cell Neurosci. 2015, 9. [CrossRef] [PubMed]

5. Pitt, D.; Werner, P.; Raine, C.S. Glutamate excitotoxicity in a model of multiple sclerosis. Nat. Med. 2000, 6, 67-70. [CrossRef] [PubMed] 
6. Lai, T.W.; Zhang, S.; Wang, Y.T. Excitotoxicity and stroke: Identifying novel targets for neuroprotection. Prog. Neurobiol. 2014, 115, 157-188. [CrossRef] [PubMed]

7. Choi, D.W. Glutamate neurotoxicity and diseases of the nervous system. Neuron 1988, 1, 623-634. [CrossRef]

8. Zhou, X.; Hollern, D.; Liao, J.; Andrechek, E.; Wang, H. NMDA receptor-mediated excitotoxicity depends on the coactivation of synaptic and extrasynaptic receptors. Cell Death Dis. 2013, 4, e560. [CrossRef] [PubMed]

9. Jiang, Q.; Gu, Z.; Zhang, G.; Jing, G. Diphosphorylation and involvement of extracellular signal-regulated kinases (ERK1/2) in glutamate-induced apoptotic-like death in cultured rat cortical neurons. Brain Res. 2000, 857, 71-77. [CrossRef]

10. Pi, R.; Li, W.; Lee, N.T.; Chan, H.H.; Pu, Y.; Chan, L.N.; Sucher, N.J.; Chang, D.C.; Li, M.; Han, Y. Minocycline prevents glutamate-induced apoptosis of cerebellar granule neurons by differential regulation of $\mathrm{p} 38$ and Akt pathways. J. Neurochem. 2004, 91, 1219-1230. [CrossRef] [PubMed]

11. Ko, H.W.; Park, K.Y.; Kim, H.; Han, P.L.; Kim, Y.U.; Gwag, B.J.; Choi, E.J. Ca ${ }^{2+-}$ mediated activation of c-Jun N-terminal kinase and nuclear factor kappa B by NMDA in cortical cell cultures. J. Neurochem. 1998, 71, 1390-1395. [CrossRef] [PubMed]

12. Nicole, O.; Ali, C.; Docagne, F.; Plawinski, L.; MacKenzie, E.T.; Vivien, D.; Buisson, A. Neuroprotection mediated by glial cell line-derived neurotrophic factor: Involvement of a reduction of NMDA-induced calcium influx by the mitogen-activated protein kinase pathway. J. Neurosci. 2001, 21, 3024-3033. [CrossRef] [PubMed]

13. Shanley, L.J.; Irving, A.J.; Harvey, J. Leptin enhances NMDA receptor function and modulates hippocampal synaptic plasticity. J. Neurosci. 2001, 21, RC186. [CrossRef] [PubMed]

14. Choo, A.M.; Geddes-Klein, D.M.; Hockenberry, A.; Scarsella, D.; Mesfin, M.N.; Singh, P.; Patel, T.P.; Meaney, D.F. NR2A and NR2B subunits differentially mediate MAP kinase signaling and mitochondrial morphology following excitotoxic insult. Neurochem. Int. 2012, 60, 506-516. [CrossRef] [PubMed]

15. Fan, J.; Gladding, C.M.; Wang, L.; Zhang, L.Y.; Kaufman, A.M.; Milnerwood, A.J.; Raymond, L.A. P38 MAPK is involved in enhanced NMDA receptor-dependent excitotoxicity in YAC transgenic mouse model of Huntington disease. Neurobiol. Dis. 2012, 45, 999-1009. [CrossRef] [PubMed]

16. Dar, N.J.; Satti, N.K.; Dutt, P.; Hamid, A.; Ahmad, M. Attenuation of Glutamate-Induced Excitotoxicity by Withanolide-A in Neuron-Like Cells: Role for PI3K/Akt/MAPK Signaling Pathway. Mol. Neurobiol. 2017, 55, 2725-2739. [CrossRef] [PubMed]

17. Yang, X.R.; Sun, P.; Qin, H.P.; Si, P.P.; Sun, X.F.; Zhang, C. Involvement of MAPK pathways in NMDA-induced apoptosis of rat cortical neurons. Sheng Li Xue Bao 2012, 64, 609-616. [PubMed]

18. Hashimoto, Y.; Niikura, T.; Tajima, H.; Yasukawa, T.; Sudo, H.; Ito, Y.; Kita, Y.; Kawasumi, M.; Kouyama, K.; Doyu, M.; et al. A rescue factor abolishing neuronal cell death by a wide spectrum of familial Alzheimer's disease genes and Abeta. Proc. Natl. Acad Sci. USA 2001, 98, 6336-6341. [CrossRef] [PubMed]

19. Hashimoto, Y.; Ito, Y.; Niikura, T.; Shao, Z.; Hata, M.; Oyama, F.; Nishimoto, I. Mechanisms of neuroprotection by a novel rescue factor humanin from Swedish mutant amyloid precursor protein. Biochem. Biophys. Res. Commun. 2001, 283, 460-468. [CrossRef] [PubMed]

20. Tajima, H.; Niikura, T.; Hashimoto, Y.; Ito, Y.; Kita, Y.; Terashita, K.; Yamazaki, K.; Koto, A.; Aiso, S.; Nishimoto, I. Evidence for in vivo production of Humanin peptide, a neuroprotective factor against Alzheimer's disease-related insults. Neurosci. Lett. 2002, 324, 227-231. [CrossRef]

21. Zapala, B.; Kaczynski, L.; Kiec-Wilk, B.; Staszel, T.; Knapp, A.; Thoresen, G.H.; Wybranska, I.; Dembinska-Kiec, A. Humanins, the neuroprotective and cytoprotective peptides with antiapoptotic and anti-inflammatory properties. Pharmacol. Rep. 2010, 62, 767-777. [CrossRef]

22. Kumfu, S.; Charununtakorn, S.T.; Jaiwongkam, T.; Chattipakorn, N.; Chattipakorn, S.C. Humanin Exerts Neuroprotection during Cardiac Ischemia-Reperfusion Injury. J. Alzheimers Dis. 2018, 61, 1343-1353. [CrossRef] [PubMed]

23. Cui, A.L.; Zhang, Y.H.; Li, J.Z.; Song, T.; Liu, X.M.; Wang, H.; Zhang, C.; Ma, G.L.; Zhang, H.; Li, K. Humanin rescues cultured rat cortical neurons from NMDA-induced toxicity through the alleviation of mitochondrial dysfunction. Drug Des. Devel. Ther. 2017, 11, 1243-1253. [CrossRef] [PubMed]

24. Alam, M.P.; Bilousova, T.; Spilman, P.; Vadivel, K.; Bai, D.; Elias, C.J.; Evseenko, D.; John, V. A Small Molecule Mimetic of the Humanin Peptide as a Candidate for Modulating NMDA-Induced Neurotoxicity. ACS Chem. Neurosci. 2018, 9, 462-468. [CrossRef] [PubMed] 
25. Zhao, J.; Wang, D.; Li, L.; Zhao, W.; Zhang, C. Protective effects of humanin on okadaic Acid-induced neurotoxicities in cultured cortical neurons. Neurochem. Res. 2014, 39, 2150-2159. [CrossRef] [PubMed]

26. Niikura, T.; Hashimoto, Y.; Tajima, H.; Nishimoto, I. Death and survival of neuronal cells exposed to Alzheimer's insults. J. Neurosci. Res. 2002, 70, 380-391. [CrossRef] [PubMed]

27. Kumfu, S.; Charununtakorn, S.T.; Jaiwongkam, T.; Chattipakorn, N.; Chattipakorn, S.C. Humanin prevents brain mitochondrial dysfunction in a cardiac ischaemia-reperfusion injury model. Exp. Physiol. 2016, 101, 697-707. [CrossRef] [PubMed]

28. Klein, L.E.; Cui, L.; Gong, Z.; Su, K.; Muzumdar, R. A humanin analog decreases oxidative stress and preserves mitochondrial integrity in cardiac myoblasts. Biochem. Biophys. Res. Commun. 2013, 440, 197-203. [CrossRef] [PubMed]

29. Sattler, R.; Charlton, M.P.; Hafner, M.; Tymianski, M. Distinct influx pathways, not calcium load, determine neuronal vulnerability to calcium neurotoxicity. J. Neurochem. 1998, 71, 2349-2364. [CrossRef] [PubMed]

30. Cui, A.L.; Li, J.Z.; Feng, Z.B.; Ma, G.L.; Gong, L.; Li, C.L.; Zhang, C.; Li, K. Humanin rescues cultured rat cortical neurons from NMDA-induced toxicity not by NMDA receptor. Sci. World J. 2014, 2014. [CrossRef] [PubMed]

31. Harada, M.; Habata, Y.; Hosoya, M.; Nishi, K.; Fujii, R.; Kobayashi, M.; Hinuma, S. N-Formylated humanin activates both formyl peptide receptor-like 1 and 2. Biochem. Biophys. Res. Commun. 2004, 324, $255-261$. [CrossRef] [PubMed]

32. Ying, G.; Iribarren, P.; Zhou, Y.; Gong, W.; Zhang, N.; Yu, Z.X.; Le, Y.; Cui, Y.; Wang, J.M. Humanin, a newly identified neuroprotective factor, uses the $\mathrm{G}$ protein-coupled formylpeptide receptor-like-1 as a functional receptor. J. Immunol. 2004, 172, 7078-7085. [CrossRef] [PubMed]

33. Hashimoto, Y.; Kurita, M.; Aiso, S.; Nishimoto, I.; Matsuoka, M. Humanin inhibits neuronal cell death by interacting with a cytokine receptor complex or complexes involving CNTF receptor alpha/WSX-1/gp130. Mol. Biol. Cell 2009, 20, 2864-2873. [CrossRef] [PubMed]

34. Garcia-Martinez, E.M.; Sanz-Blasco, S.; Karachitos, A.; Bandez, M.J.; Fernandez-Gomez, F.J.; Perez-Alvarez, S.; de Mera, R.M.; Jordan, M.J.; Aguirre, N.; Galindo, M.F.; et al. Mitochondria and calcium flux as targets of neuroprotection caused by minocycline in cerebellar granule cells. Biochem. Pharmacol. 2010, 79, 239-250. [CrossRef] [PubMed]

35. Borsello, T.; Clarke, P.G.; Hirt, L.; Vercelli, A.; Repici, M.; Schorderet, D.F.; Bogousslavsky, J.; Bonny, C. A peptide inhibitor of c-Jun N-terminal kinase protects against excitotoxicity and cerebral ischemia. Nat. Med. 2003, 9, 1180-1186. [CrossRef] [PubMed]

36. Centeno, C.; Repici, M.; Chatton, J.Y.; Riederer, B.M.; Bonny, C.; Nicod, P.; Price, M.; Clarke, P.G.; Papa, S.; Franzoso, G.; et al. Role of the JNK pathway in NMDA-mediated excitotoxicity of cortical neurons. Cell Death Differ. 2007, 14, 240-253. [CrossRef] [PubMed]

37. Hirt, L.; Badaut, J.; Thevenet, J.; Granziera, C.; Regli, L.; Maurer, F.; Bonny, C.; Bogousslavsky, J. D-JNKI1, a cell-penetrating c-Jun-N-terminal kinase inhibitor, protects against cell death in severe cerebral ischemia. Stroke 2004, 35, 1738-1743. [CrossRef] [PubMed]

38. Legos, J.J.; Erhardt, J.A.; White, R.F.; Lenhard, S.C.; Chandra, S.; Parsons, A.A.; Tuma, R.F.; Barone, F.C. SB 239063, a novel p38 inhibitor, attenuates early neuronal injury following ischemia. Brain Res. 2001, 892, 70-77. [CrossRef]

39. Alessandrini, A.; Namura, S.; Moskowitz, M.A.; Bonventre, J.V. MEK1 protein kinase inhibition protects against damage resulting from focal cerebral ischemia. Proc. Natl. Acad. Sci. USA. 1999, 96, 12866-12869. [CrossRef] [PubMed]

40. Skaper, S.D.; Facci, L.; Strijbos, P.J. Neuronal protein kinase signaling cascades and excitotoxic cell death. Ann. N. Y. Acad. Sci. 2001, 939, 11-22. [CrossRef] [PubMed]

41. Karmarkar, S.W.; Bottum, K.M.; Krager, S.L.; Tischkau, S.A. ERK/MAPK is essential for endogenous neuroprotection in SCN2.2 cells. PLoS ONE 2011, 6, e23493. [CrossRef] [PubMed]

42. Zhuang, S.; Schnellmann, R.G. A death-promoting role for extracellular signal-regulated kinase. J. Pharmacol. Exp. Ther. 2006, 319, 991-997. [CrossRef] [PubMed]

43. Kelkel, M.; Cerella, C.; Mack, F.; Schneider, T.; Jacob, C.; Schumacher, M.; Dicato, M.; Diederich, M. ROS-independent JNK activation and multisite phosphorylation of Bcl-2 link diallyl tetrasulfide-induced mitotic arrest to apoptosis. Carcinogenesis 2012, 33, 2162-2171. [CrossRef] [PubMed] 
44. Na, H.K.; Kim, E.H.; Choi, M.A.; Park, J.M.; Kim, D.H.; Surh, Y.J. Diallyl trisulfide induces apoptosis in human breast cancer cells through ROS-mediated activation of JNK and AP-1. Biochem. Pharmacol. 2012, 84, 1241-1250. [CrossRef] [PubMed]

45. Jeong, J.B.; Choi, J.; Baek, S.J.; Lee, S.H. Reactive oxygen species mediate tolfenamic acid-induced apoptosis in human colorectal cancer cells. Arch. Biochem. Biophys. 2013, 537, 168-175. [CrossRef] [PubMed]

46. Liu, J.; Chang, F.; Li, F.; Fu, H.; Wang, J.; Zhang, S.; Zhao, J.; Yin, D. Palmitate promotes autophagy and apoptosis through ROS-dependent JNK and p38 MAPK. Biochem. Biophys. Res. Commun. 2015, 463, $262-267$. [CrossRef] [PubMed]

47. Li, Y.; Yang, X.; Ma, C.; Qiao, J.; Zhang, C. Necroptosis contributes to the NMDA-induced excitotoxicity in rat's cultured cortical neurons. Neurosci. Lett. 2008, 447, 120-123. [CrossRef] [PubMed]

48. Liu, Y.; Zhang, Y.; Lin, L.; Lin, F.; Li, T.; Du, H.; Chen, R.; Zheng, W.; Liu, N. Effects of bone marrow-derived mesenchymal stem cells on the axonal outgrowth through activation of PI3K/AKT signaling in primary cortical neurons followed oxygen-glucose deprivation injury. PLoS ONE 2013, 8, e78514. [CrossRef] [PubMed]

49. Veronesi, M.C.; Yard, M.; Jackson, J.; Lahiri, D.K.; Kubek, M.J. An analog of thyrotropin-releasing hormone (TRH) is neuroprotective against glutamate-induced toxicity in fetal rat hippocampal neurons in vitro. Brain Res. 2007, 1128, 79-85. [CrossRef] [PubMed]

(C) 2018 by the authors. Licensee MDPI, Basel, Switzerland. This article is an open access article distributed under the terms and conditions of the Creative Commons Attribution (CC BY) license (http:/ / creativecommons.org/licenses/by/4.0/). 